\title{
Ecological conditions of the vegetation and vascular plant species distribution in the selected forest seepage spring area (NE Poland) based on a fine-scale assessment
}

\author{
Dorota Gawenda-Kempczyńska
}

Department of Biology and Pharmaceutical Botany, Nicolaus Copernicus University in Toruń, Ludwik Rydygier

Collegium Medicum in Bydgoszcz, M. Curie Skłodowskiej 9, 85-094 Bydgoszcz, Poland,

e-mail: dgawenda@cm.umk.pl

\begin{abstract}
The existence and functioning of spring ecosystems is determined by groundwater seepage or outflow. The water seeping through the ground surface triggers off the headward and deep erosion processes, which results in the channelled shape of the lowland rheocrenic springs. Spring areas significantly contribute to the floristic, phytocoenotic and landscape diversity. The literature on the vegetation cover of lowland spring ecosystems is scarce. Most papers refer to the identification of their flora and plant communities, less frequently - the relationships between habitat conditions and vegetation. The studies indicate that $\mathrm{pH}$ and moisture content are the main factors determining the composition and species diversity of ecosystems supplied by groundwater.

My study presents a detailed geobotanical analysis performed on one forested spring area (together with an adjacent area) of 0.378 ha, which was divided into 945 study plots - squares with an area of $4 \mathrm{~m}^{2}$. Three zones were distinguished in the studied spring area: the bottom with a specific mosaic pattern caused by the presence of streams, water seepage sites and mineral islands, the steep slope and the surrounding area. A detailed map of habitats and the actual vegetation was prepared. A list of vascular plant species was compiled for each study plot, based on which maps with the distribution of mean Ellenberg's indicator values were created. Statistically significant differences in the variance of Ellenberg's indicator values between the distinguished zones were demonstrated (ANOVA), and the correlations between the ecological indicators within a given zone were calculated. CCA analysis of plant communities and the distinguished zones revealed that the occurrence of e.g. Carici remotae-Fraxinetum and non-forest plant communities of wet and moist habitats is associated with the bottom of the niche characterised by a high value of Ellenberg's moisture indicator F. Whereas the Acer platanoides-Tilia cordata community and the Tilio-Carpinetum corydaletosum association develop on the slope with high values of the temperature indicator T. Furthermore, the CCA analysis performed on the plant species and the distinguished zones confirmed the above results. It has been shown that the species composition and the distribution of plant species and plant communities in the study area are mainly determined by soil moisture content, but also by light and temperature.
\end{abstract}

Key words: spring area, species diversity, vegetation diversity, phytoindication analysis, Ellenberg's indicators.

\section{Introduction}

The existence of spring ecosystems is determined by groundwater seepage or outflow. They are distinguished from other ecosystems by e.g. unique vegetation cover. Most of the springs occur in areas with a dense surface water network, including mostly mountains and upland areas, less often - lowlands (Lachacz, 1999; Wołejko, 2000; Osadowski, 2010; Audorf et al., 2011; Chytry, 2012; Sekulová et al., 2012).
The presented study relates to a spring ecosystem of the rheocrenic nature. In this type of springs, water flowing from the geological strata creates a watercourse running off the slope with a relatively strong current. As a result of water erosion, they often occur in the form of depressions (niches) with steep slopes and relatively large altitude differences over a small area. They are characterised by a mosaic structure of the bottom with water seepage sites and many streams. Such springs occur alone or in groups (Alfaro \& Wallace, 1994; Springer \& Stevens, 2009; Wołejko, 
2000). There are not many literature references on the vegetation cover of rheocrenic spring ecosystems. More studies relate to helocrenic sites (where groundwater infiltrates through the soil layer and creates marshy lands overgrown with vegetation) located in mountain areas, whereas lowland ecosystems have been neglected.

Due to specific habitat conditions, spring ecosystems are refugia of many rare, protected and threatened plant species, and place where interesting plant communities occur. They significantly contribute to the floristic, phytocoenotic and landscape diversity (Wołejko, 2002; Gawenda-Kempczyńska, 2005; Hájek et al., 2005; Osadowski \& Żukowska, 2009).

The hitherto published papers on ecosystems are mainly related to the identification of their flora and vegetation (Mass, 1959; Hinterlang, 1992; Herbich, 1994; Zechmaister \& Mucina, 1994; Beierkuhnlein, 1999a, 1999b; Beierkuhnlein \& Schmidt, 1999; Kucharski \& Filipiak, 1999; Peintinger \& Beierkuhnlein, 1999; Załuski \& Gawenda, 1999; Wołeko, 2000; Kliment et al., 2008; Osadowski, 2008; Sekulová et al., 2011). Physical and chemical characteristics of water and soil are rarely included in the analysis, and only few papers deal with relationships between habitat conditions and vegetation cover. The publications indicate that in addition to the obvious effect of moisture, $\mathrm{pH}$ is the main factor determining the species composition and diversity of spring ecosystems (Wołeko, 2000; Hájek et al., 2002; Hájková \& Hájek, 2003; Hájek \& Hekera, 2004; Strohbach et al., 2009; Zang et al., 2009; Osadowski, 2010; Kløve et al., 2011; Sekulová et al., 2012) which appear to be sustainable systems in terms of hydrochemical and hydrophysical factors (Hájková et al., 2004; Audorf et al., 2009, 2011; Kapfer et al., 2012). In more detailed geobotanical studies of spring ecosystems, transects of stratigraphic cross-sections or large-scale maps of actual vegetation were presented (Mass, 1959; Wołejko, 1991, 2000; Wołejko et al., 1994; Bohn, 1996; Osadowski, 2000, 2010; Faliński, 2002; Grootjans et al., 2005). Most of the studies present a comparison of different spring sites, and only few of them focused on the detailed geobotanical analysis taking into account the habitat and vegetation diversity of a single spring area (Wołejko et al., 1994; Grootjans et al., 1999). The spring areas represent ecosystems of a high nature conservation value and hence require further detailed studies.

The objective of the present work is to demonstrate the habitat and vegetation heterogeneity of one spring area and to determine how the geomorphology and habitat conditions influence the species composition and species distribution in a small forested spring area.

\section{Material and methods}

The study area is located in NE Poland (Górzno-Lidzbark Landscape Park, Brodnica Forest District), in oak-hornbeam forests with planted pine (Fig. 1). It covers the spring area (bottom and slope of the niche) and its immediate surroundings - referred to in this paper as zones. The study area is permanently marked in the field, making it possible to carry out the monitoring studies (coordinates of the center of the area: N 5314'30.67', E 19³9'48.02'"). It has a shape of a rectangle with dimensions: $70 \mathrm{~m}$ x $54 \mathrm{~m}$ (3780 $\mathrm{m}^{2}$ ). The area was divided into 945 squares with a $2 \mathrm{~m}$ side. The squares are the basic study plots (Fig. 2). The size of the basic study plots $\left(4 \mathrm{~m}^{2}\right)$ results from the prerequisite to capture the mosaic structure.

Based on the defined network of study plots, detailed geobotanical studies were carried out. The map of habitats was compiled, which included:

- water seepage - marshy, strongly hydrated sites with intensive water seepage and hydrogenic soil with a humus horizon of large thickness,

- weak water flow - sites with weak, only surface water flow at a depth of a few millimetres, with a firm, stable substrate, and well-hydrated hydrogenic soil with a humus horizon of a very small thickness,

- water flow - streams of flowing water, characterised by a stable mineral substrate and no humus layer,

- tree islands - mineral elevations in the form of islands and clumps (clusters) of trees,

- the slope with autogenic soil,

- the immediate surroundings of the spring ecosystem extending from the edge of the slope, characterised by the presence of autogenic soil.

The actual vegetation map was compiled based on homogeneous phytocoenoses (vegetation patches), and plant communities were identified on the basis of species composition of a given phytocoenosis (Załuski et al., 2004). Plant communities from the classes Alnetea glutinosae and Querco-Fagetea were identified following W. Matuszkiewicz's classification (2001). Plant communities from the classes Lemnetea minoris, Phragmitetea australis and Artemisietea vulgaris were identified based on the paper by Brzeg and Wojterska (2001). The Cardamino-Alnetum was identified according to Wołejko (2000), and the Acer platanoides-Tilia cordata plant community - according to Jutrzenka-Trzebiatowski (1995).

Detailed lists of vascular plant species in the study plots of $4 \mathrm{~m}^{2}$ were made in 2001. During the fieldwork, the cover of each species was estimated in each plot according to the three-point scale: $1-<25 \% ; 2-25-50 \% ; 3->50 \%$. Crown projection for trees and shrubs was made on the grid of squares. Prepared in this way cartogram was used to determine the cover of tree and shrub species in each square according to the above three-point cover scale. The 


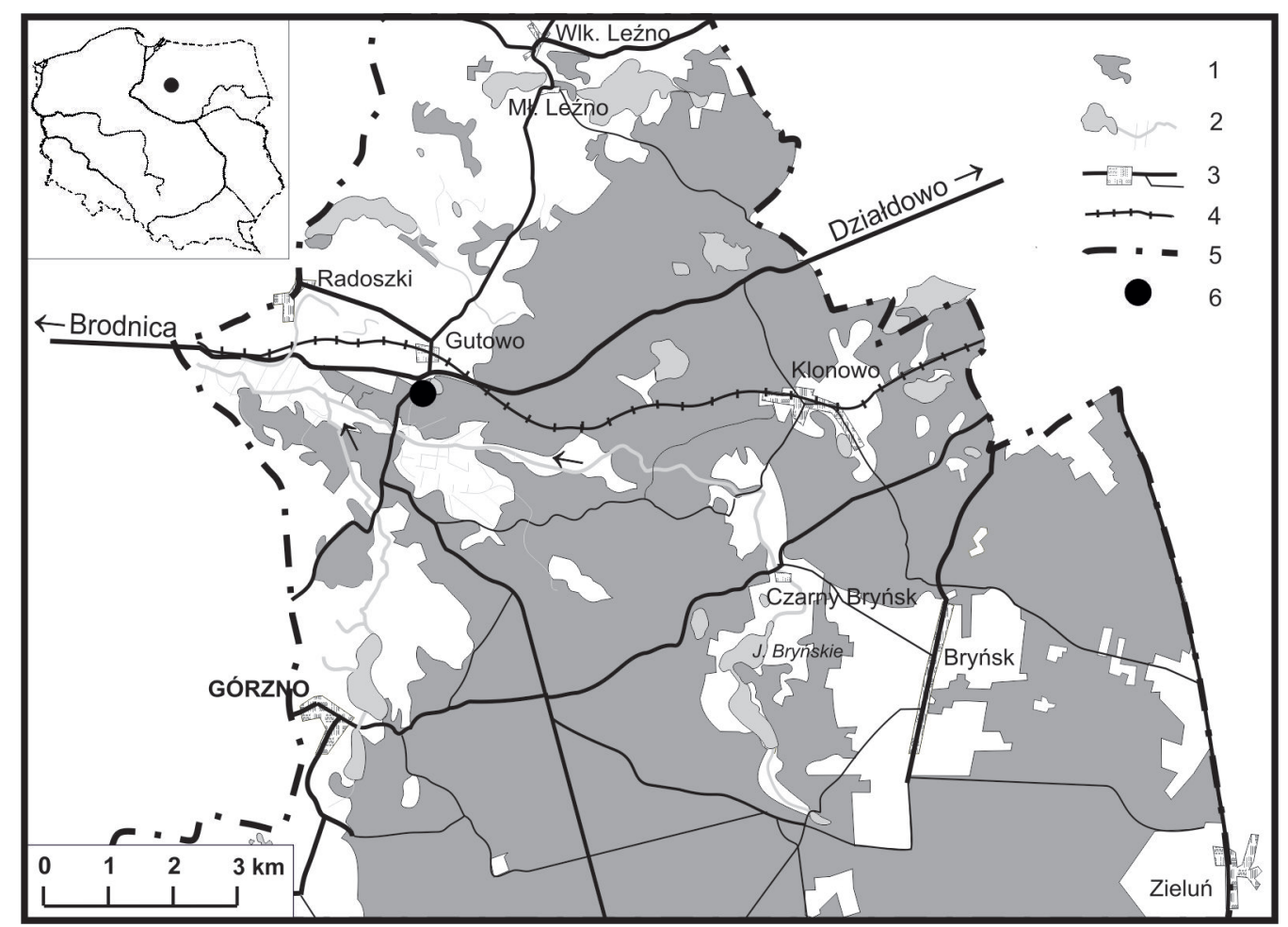

Figure 1. Location of the object; 1 - forests, 2 - surface waters, 3 - towns and main roads, 4 - railways, 5 - boundary of Górzno-Lidzbark Landscape Park, 6 - locality of spring area

nomenclature of species was accepted after Mirek et al. (2002). The affinity with socio-ecological groups was determined for each species (Zechmaister \& Mucina, 1994; Brzeg \& Wojterska, 2001; Matuszkiewicz, 2001).

The percentage of each habitat and each plant community was calculated (with an accuracy of $1 \%$ of the covered area) for each study plot, based on the prepared maps: the map of habitats and the map of actual vegetation. For this purpose, the LabVIEW software was used. The calculated percentage of habitats and vegetation was used in the multivariate analysis.

The weighted average of Ellenberg's indicator values was calculated for each study plot (Ellenberg et al., 2001). Light (L), temperature (T), moisture (F), reaction $(\mathrm{R})$, nutrient availability $(\mathrm{N})$ and continentality $(\mathrm{K})$, where cover of each species in a given study plot was used as a weight (Diekmann, 2003). The obtained values were used to draw maps with the distribution of averaged ecological indicators. Values of indicators are presented on the maps in grayscale. The lowest value of an indicator is marked in white, the highest - in black. In order to demonstrate the significance of differences between the identified zones of the spring niche, the analysis of variance ANOVA was conducted. Correlations of indicators and their statistical significance inside the zones were calculated (the software Statistica).

DCA analysis, the result of which was a unimodal distribution of plant species and plant communities along gradients, allow to perform Canonical Correspondence Analysis (Jongman et al., 1995). The CCA analysis (ter Braak, 1986; ter Braak \& Šmilauer, 2002) was performed on the plant species in relation to the type of habitat and the percentage of plant communities in relation to the type of habitat.

Only the maximum cover of tree and shrub species was used in the numerical analysis, regardless of their occurrence in vegetation layers.

The median number of vascular species was calculated for each zone (the surroundings, the slope and the bottom). Only study plots with $>90 \%$ cover of a given zone were included in the calculations. 
A
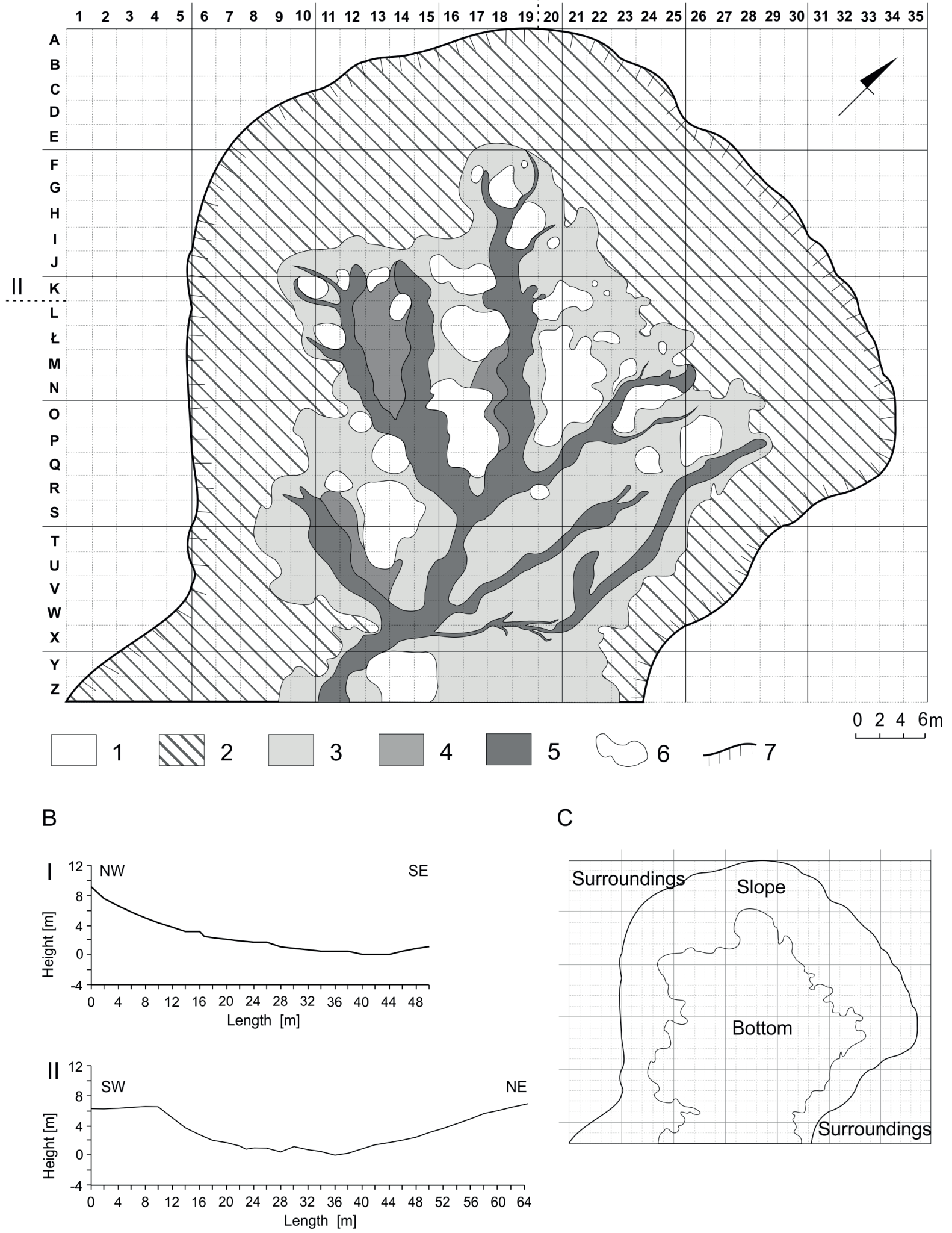

Figure 2. Habitat conditions and geomorphology of the forested spring area; A - habitats heterogeneity: 1 - surroundings, 2 - slope, 3 - water seepage, 4 - weak water flow, 5 - water flow, 6 - tree islands, 7 - edge of the slope; B - profiles of altitude differences: I - profile along the seepage spring niche (line 19), II - profile across the seepage spring niche (line $\mathrm{K}$ ); $\mathrm{C}$ - zones of the study area 


\section{Results}

\subsection{Habitat conditions}

Heterogeneity of habitat conditions in the study area is presented in Figure 2A. Three zones were distinguished based on the geomorphology, the type of soil, substrate and moisture content: the surroundings, the slope and the bottom (Fig. 2C). The bottom is characterised by a mosaic of microhabitats. Habitats affected by groundwater dominate in the study area, i.e. seeps, streams, places with a low infiltration rate and mineral elevations overgrown with clusters of trees. Hydrogenic soil with a relatively thick humus horizon developed in places of seeps, while autogenic soil developed on elevations with clusters of trees. The bottom of the niche is surrounded by a relatively steep slope, clear- ly distinguishable from the surroundings. Autogenic soils occur on the slope and in the slightly inclined surroundings of the niche.

Elevation profiles made across and along the spring niche (Fig. 2B) indicate a channelled shape of the niche. Differences in the relative altitude between the bottom of the niche and the highest point on the edge of the slope is more than $8 \mathrm{~m}$.

\subsection{Phytosociological and species diversity}

Vegetation of the spring area is very heterogeneous (Fig. 3) - 14 vegetation units with almost concentric distribution were identified. Non-forest communities occur at the bottom of the niche: Lemnetum trisulcae, rush associations Glycerietum plicato-nemoralis and Cardamino-Beruletum

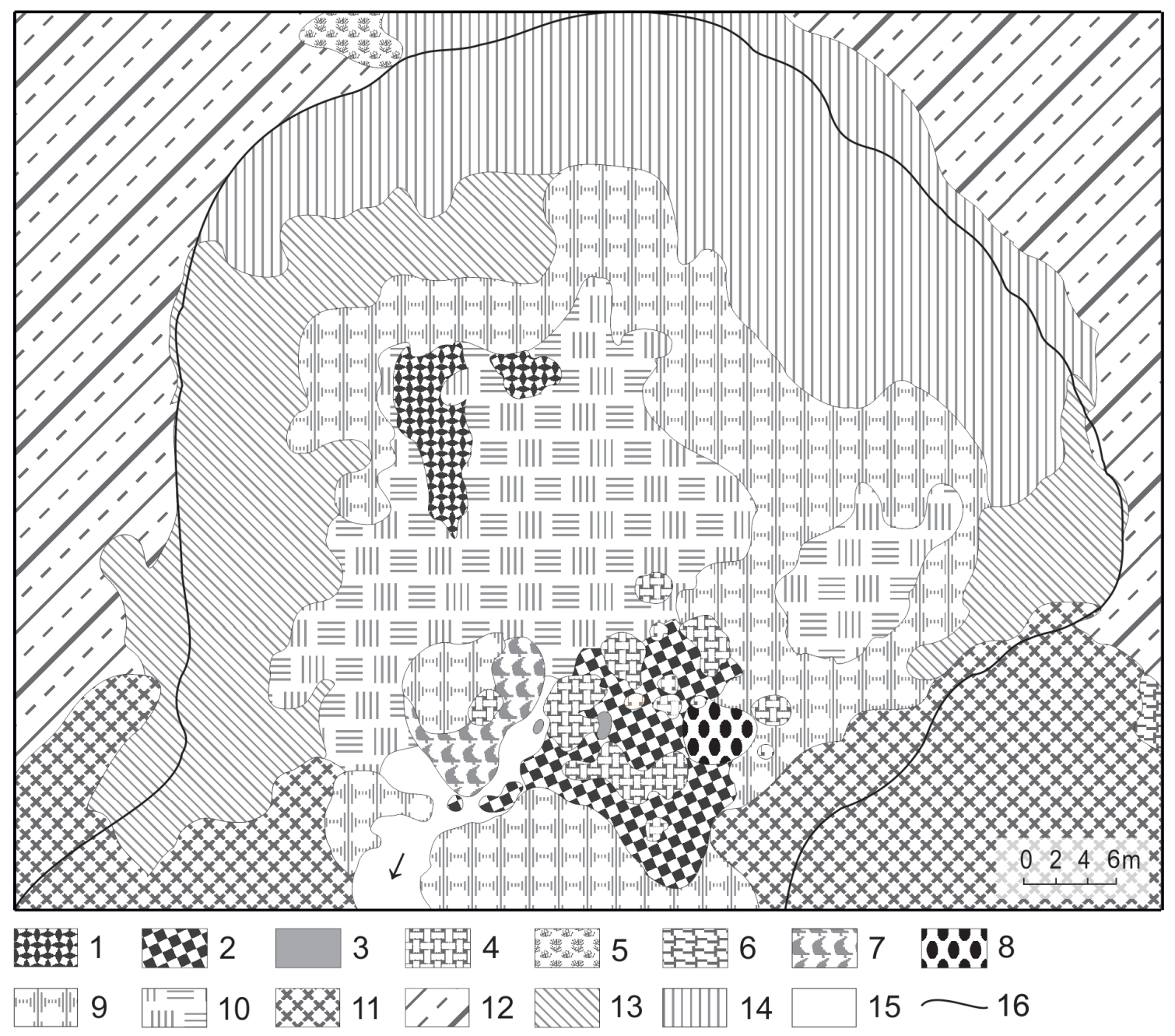

Figure 3. Actual vegetation (Załuski i in. 2004, changed); 1 - Lemnetum trisulcae, 2 - Glycerietum plicato-nemoralis, 3 - Cardamino-Beruletum erecti, 4 - Eupatorietum cannabini, 5 - Alliario-Chaerophylletum temuli, 6 - Rumicetum obtusifolii, 7 - Cardamino-Alnetum developmental stages, 8 - Ribes nigrum community, 9 - Fraxino-Alnetum, 10 - Carici remotae-Fraxinetum impoverished form, 11 - Ficario-Ulmetum minoris, 12 - Tilio-Carpinetum typicum form with Pinus sylvestris, 13 - Tilio-Carpinetum corydaletosum, 14 - Acer platanoides-Tilia cordata community, 15 - stream, 16 - edge of the slope 
Table 1. The share of socio-ecological groups

\begin{tabular}{|c|c|c|}
\hline \multicolumn{2}{|r|}{ Socio-ecological group } & Number of species \\
\hline \multicolumn{3}{|c|}{ Forest species } \\
\hline 1 & Querco-Fagetea & 38 \\
\hline 2 & Rhamno-Prunetea & 7 \\
\hline 3 & Alnetea glutinosae & 4 \\
\hline 4 & Vaccinio-Piceetea & 3 \\
\hline 5 & Inne leśne & 16 \\
\hline \multicolumn{3}{|c|}{ Non-forest species } \\
\hline 6 & Artemisietea vulgaris & 28 \\
\hline 7 & Molinio-Arrhenatheretea & 22 \\
\hline 8 & Phragmitetea & 8 \\
\hline 9 & Trifolio-Geranietea & 4 \\
\hline 10 & Stellarietea mediae & 4 \\
\hline 11 & Epilobietea angustifolii & 2 \\
\hline 12 & Lemnetea & 2 \\
\hline 13 & Scheuchzerio-Caricetea nigrae & 1 \\
\hline 14 & Montio-Cardaminetea & 3 \\
\hline 15 & Bidentetea tripartiti & 1 \\
\hline \multicolumn{2}{|r|}{ Total } & 143 \\
\hline
\end{tabular}

erecti, the association of tall-herb vegetation Eupatorietum cannabini and the Ribes nigrum community. They occur in the complex with Carici remotae-Fraxinetum. Lemnetum trisulcae occurs in places with a gentle water flow and a thin humus layer. Glycerietum plicato-nemoralis, Eupatorietum cannabini and the Ribes nigrum community form a mosaic pattern. They occur under the canopy of trees with accumulated organic matter, near the streams, in marshy places where groundwater seepage occurs. Developmental stages of Carici remotae-Fraxinetum dominate in the central part of the niche's bottom. It is a lowland form of this association characterised by a smaller contribution of montane species. Characteristic species are represented only by Carex remota. The plant community covers habitats which are mosaics of streams, water seepage sites with marshy substrate and clusters of trees on mineral elevations.

Fraxino-Alnetum develops in the ecotone zone between the bottom of the niche and the slope, and covers waterlogged places. The Acer platanoides-Tilia cordata community and the association Tilio-Carpinetum corydaletosum grow on the slope. Tilio-Carpinetum and Ficario-Ulmetum minoris develop around the niche. Ficario-Ulmetum in the southern part of the area, in the vicinity of seeps and streams.

Only species of vascular plants were included in this paper. A total of 143 taxa from 14 phytosociological classes (Table 1) were identified within the limits of the study area, including 68 forest taxa. The class of Querco-Fagetea was represented by the largest number of species (38 species). Non-forest species were represented by 75 taxa, including mostly species from the classes Artemisietea vulgaris 28 species and Molinio-Arrhenatheretea -22 species. The class of spring habitat vegetation Montio-Cardaminetea included only 3 species (Table 1).

The largest number of herbaceous species was found at the study plots located on the slope - on average 15 taxa, followed by 14 species identified within the study plots at the bottom, and 13 species in the surroundings.

\subsection{Phytoindication analysis}

In the following description, the numbers in parentheses indicate Ellenberg's indicator values. Plant species occurring in the study area represent a complete range of the light indicator L - with single taxa growing in deep shade (L1) and taxa of full-spectrum light (L9). The temperature indicator $\mathrm{T}$ comprises species from cold (T3) to hot (T7) habitats, and species with a moderate indicator value - T5 and T6 - considerably dominate. Taking into account the soil moisture content F, both species of dry (F4) and aquatic habitats (F11, F12) occur in the area, with the dominance of species preferring moderately wet and wet habitats (F5-F10). There is a high percentage of species with undetermined preferences for reaction $\mathrm{R}$, but most of the species are calciphilous (indicator R6-R8). Only several species are taxa of acid and moderately acid habitats (R3-R5). Species preferring moderate and high content of nitrogen (N4-N8) dominate. Most species are suboceanic taxa, while continental species (K2-K8) have insignificant contribution.

The distribution of average indicator values for the study plots coincides with the outline of the niche bottom, the slope and the surrounding area, derived from the mapping of habitats (Fig. 4). The highest mean value of the light indicator L (Table 2) was determined at the bottom of the niche (5.07) and the lowest - on the slope (4.70). Also the moisture index $(\mathrm{F})$ had the highest values at the bottom of the niche, i.e. above 6 at most of the study plots. The highest mean value of the temperature indicator $\mathrm{T}$ was determined for plots located on the slope -4.21 , and the lowest at the bottom -3.17 . There were small differences in the reaction indicator $\mathrm{R}$ values within the limits of the spring niche (slope and bottom). The mean value at all study plots ranges from 4.05 for the slope to 4.21 for the bottom. Much lower values were obtained for plots situated in the surroundings of the niche (3.32). The mean value 
L

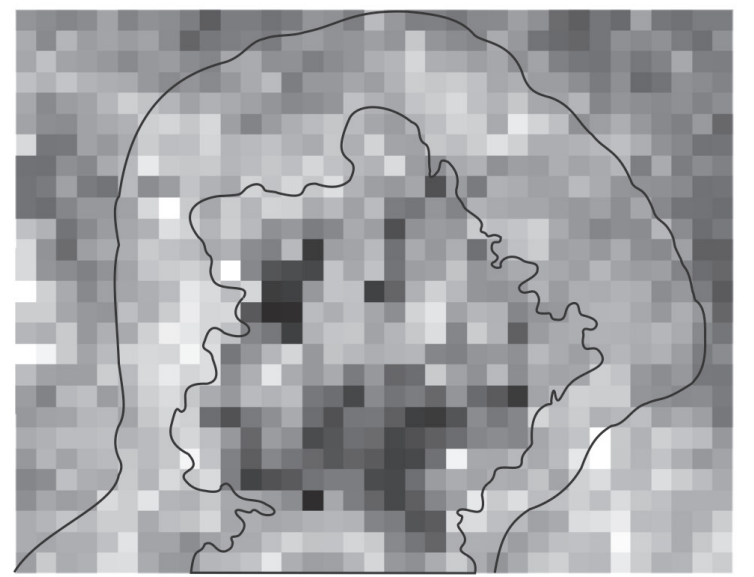

$\mathrm{F}$

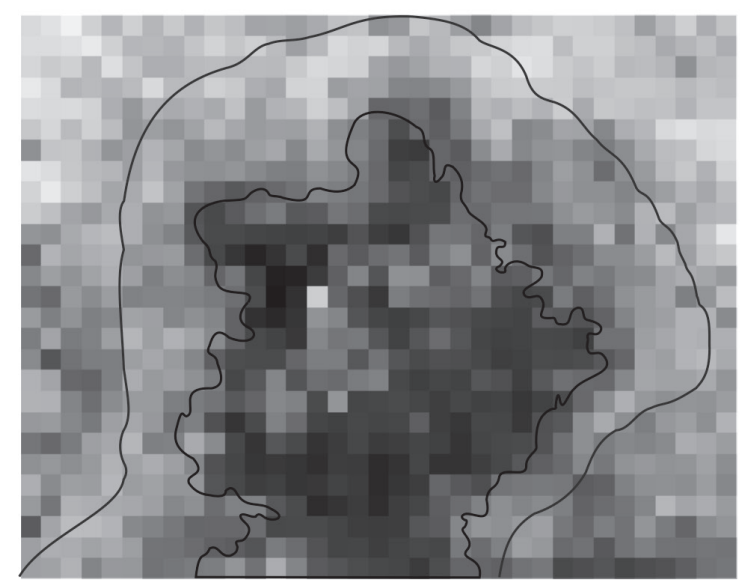

$\mathrm{N}$

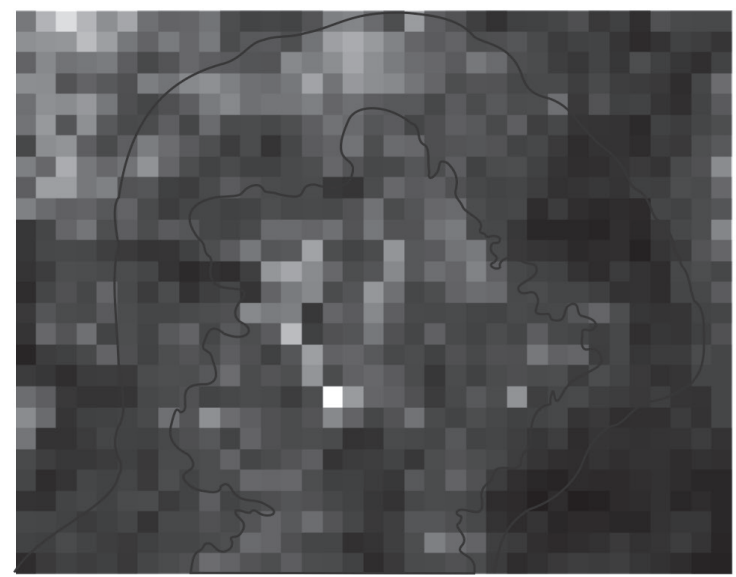

$\mathrm{T}$
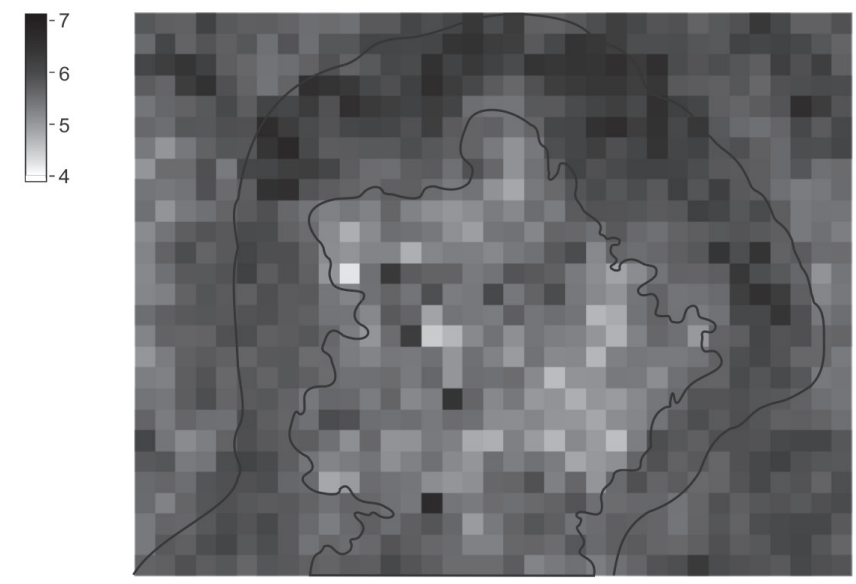

$\mathrm{R}$

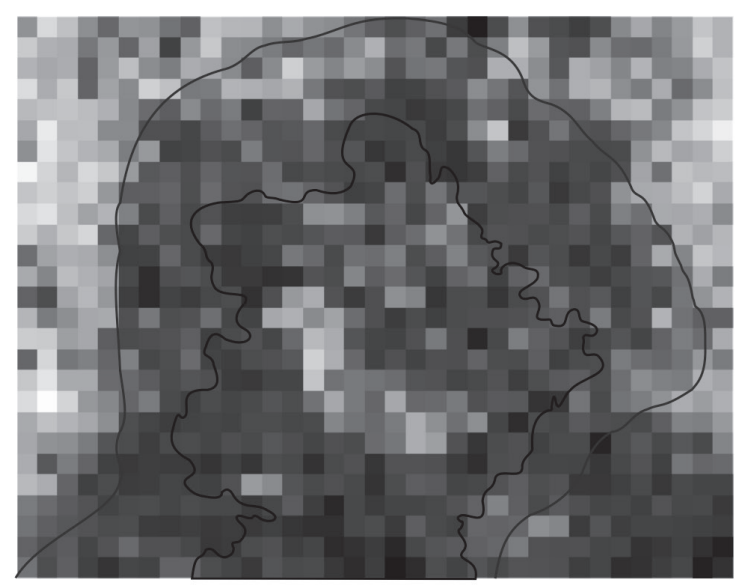

$\mathrm{K}$

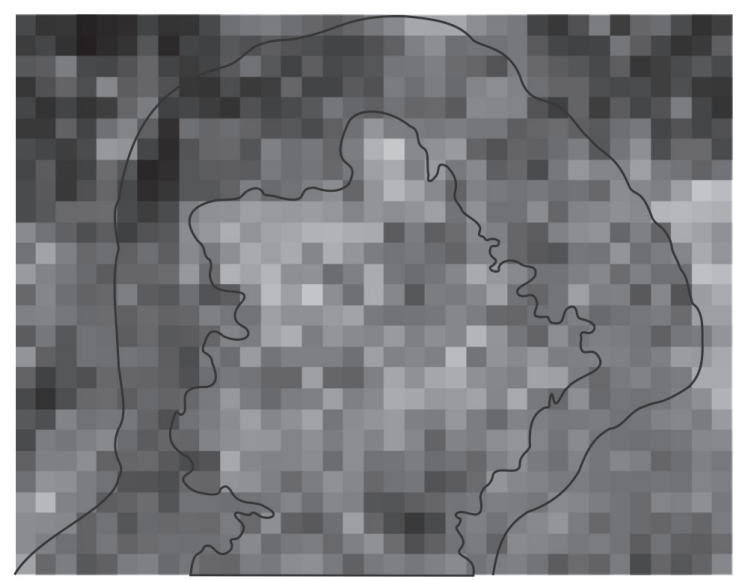

Figure 4. Maps of habitat conditions assessed by the averaged ecological indicators; $\mathrm{L}-$ light, $\mathrm{T}-$ temperature, $\mathrm{F}-$ moisture, $\mathrm{R}-$ reaction, $\mathrm{N}$ - nutrients, $\mathrm{K}$ - continentality 
Table 2. Statistics of Ellenberg's indicators values in distinguished zones

\begin{tabular}{|c|c|c|c|c|c|c|c|}
\hline \multirow{2}{*}{\multicolumn{2}{|c|}{ Zone }} & \multicolumn{6}{|c|}{ Ellenberg's indicators } \\
\hline & & $\mathbf{L}$ & $\mathbf{T}$ & $\mathbf{F}$ & $\mathbf{R}$ & $\mathbf{N}$ & $\mathbf{K}$ \\
\hline \multirow{4}{*}{ Surroundings } & $\min$ & 3.87 & 2.53 & 2.35 & 1.06 & 2.96 & 2.57 \\
\hline & $\max$ & 5.74 & 5.23 & 6.31 & 6.00 & 7.35 & 5.00 \\
\hline & mean & 4.95 & 3.85 & 4.13 & 3.32 & 5.78 & 3.62 \\
\hline & SD & 0.370 & 0.529 & 0.780 & 0.895 & 0.814 & 0.425 \\
\hline \multirow{4}{*}{ Slope } & $\min$ & 4.00 & 2.97 & 2.97 & 2.08 & 3.76 & 2.90 \\
\hline & $\max$ & 5.35 & 5.53 & 5.96 & 5.38 & 7.25 & 4.75 \\
\hline & mean & 4.70 & 4.21 & 4.53 & 4.05 & 5.72 & 3.59 \\
\hline & SD & 0.261 & 0.472 & 0.625 & 0.524 & 0.695 & 0.290 \\
\hline \multirow{4}{*}{ Bottom } & $\min$ & 3.93 & 1.33 & 3.29 & 2.00 & 2.50 & 2.55 \\
\hline & $\max$ & 6.60 & 5.40 & 9.08 & 6.00 & 6.79 & 4.26 \\
\hline & mean & 5.07 & 3.17 & 6.14 & 4.21 & 5.42 & 3.27 \\
\hline & SD & 0.523 & 0.633 & 0.934 & 0.626 & 0.566 & 0.273 \\
\hline
\end{tabular}

Note. min - minimal value, max - maximal value, mean - mean value, $\mathrm{SD}$ - standard deviation, $\mathrm{L}$ - light, $\mathrm{T}$ - temperature, $\mathrm{F}$ - moisture, $\mathrm{R}$ - reaction, $\mathrm{N}$ - nutrients, $\mathrm{K}$ - continentality

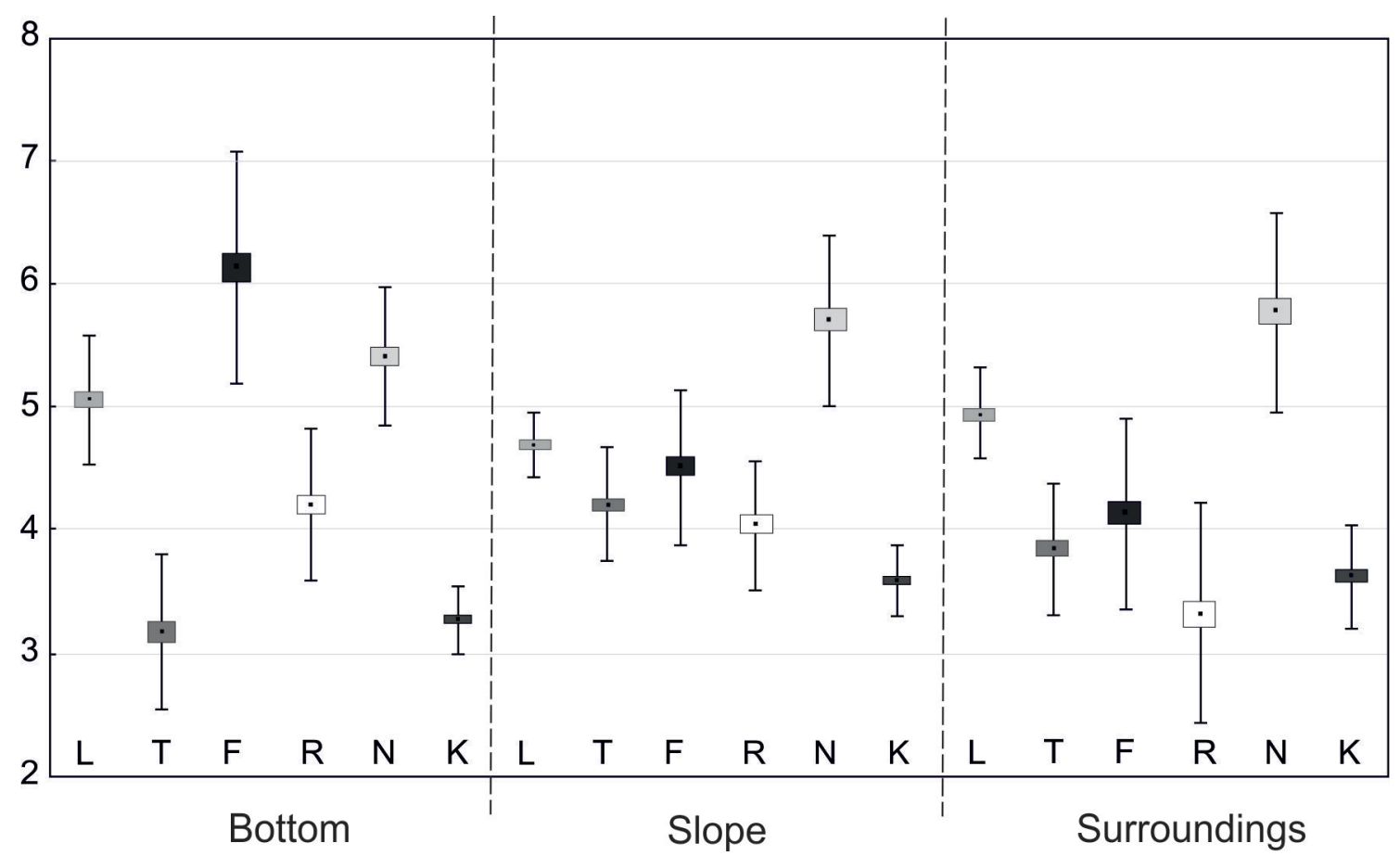

Figure 5. Mean values of Ellenberg indicators in zones; box - standard error, whisker - standard deviation, L - light, $\mathrm{T}$ - temperature, $\mathrm{F}$ - moisture, $\mathrm{R}$ - reaction, $\mathrm{N}$ - nutrients, $\mathrm{K}$ - continentality 
Table 3. Correlations of Ellenberg indicators within zones of the study area

\begin{tabular}{|c|c|c|c|c|c|c|c|}
\hline \multicolumn{2}{|c|}{$\begin{array}{l}\text { Ellenberg's } \\
\text { indicators }\end{array}$} & $\mathbf{L}$ & $\mathbf{T}$ & $\mathbf{F}$ & $\mathbf{R}$ & $\mathbf{N}$ & $\mathbf{K}$ \\
\hline \multirow{6}{*}{ 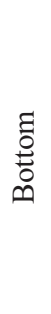 } & $\mathbf{L}$ & 1.000 & & & & & \\
\hline & $\mathbf{T}$ & 0.099 & 1.000 & & & & \\
\hline & $\mathbf{F}$ & 0.607 & -0.171 & 1.000 & & & \\
\hline & $\mathbf{R}$ & -0.248 & 0.111 & 0.261 & 1.000 & & \\
\hline & $\mathbf{N}$ & -0.273 & -0.330 & -0.007 & 0.304 & 1.000 & \\
\hline & $\mathbf{K}$ & -0.033 & 0.266 & -0.155 & 0.099 & 0.191 & 1.000 \\
\hline \multirow{6}{*}{$\frac{\check{\partial}}{\tilde{\sigma}}$} & $\mathrm{L}$ & 1.000 & & & & & \\
\hline & $\mathbf{T}$ & 0.310 & 1.000 & & & & \\
\hline & F & -0.252 & -0.551 & 1.000 & & & \\
\hline & $\mathbf{R}$ & -0.285 & -0.256 & 0.520 & 1.000 & & \\
\hline & $\mathbf{N}$ & -0.041 & -0.264 & 0.417 & \begin{tabular}{|l|l|}
0.306 \\
\end{tabular} & 1.000 & \\
\hline & $\mathbf{K}$ & -0.065 & 0.306 & -0.322 & -0.161 & -0.479 & 1.000 \\
\hline \multirow{6}{*}{ 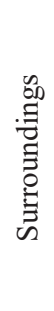 } & $\mathbf{L}$ & 1.000 & & & & & \\
\hline & $\mathbf{T}$ & -0.059 & 1.000 & & & & \\
\hline & $\mathbf{F}$ & -0.612 & -0.042 & 1.000 & & & \\
\hline & $\mathbf{R}$ & -0.512 & 0.319 & 0.552 & 1.000 & & \\
\hline & $\mathbf{N}$ & -0.413 & 0.127 & 0.627 & 0.582 & 1.000 & \\
\hline & $\mathbf{K}$ & 0.135 & 0.239 & -0.423 & -0.241 & -0.495 & 1.000 \\
\hline
\end{tabular}

Note. Bold numbers - statistically significat $(\mathrm{p}<0.05)$, gray - high values of correlation coefficients

of the nutrient availability indicator $(\mathrm{N})$ for the surroundings of the niche, the slope and the bottom were: 5.78 , $5.72,5.42$, respectively. The smallest differences between the distinguished zones were obtained for the indicator of continentality. Figure 5 presents averaged Ellenberg's indicator values for each zone. The bottom is characterised by the highest values of moisture F, light $\mathrm{L}$ and nutrient availability $\mathrm{N}$. The highest values on the slope were recorded for temperature $\mathrm{T}$.

Mean Ellenberg's indicator values for the study plots follow the normal distribution (Shapiro-Wilk test). Oneway analysis of variance ANOVA indicates that there are statistically significant differences in the indicators between the zones. Based on the post-hoc test (Scheffe test), it has been proved that Ellenberg's indicators are statistically significantly different for each zone, except for continentality $(\mathrm{K})$ and nutrient availability $(\mathrm{N})$ between the slope and the surroundings, and the light (L) between the surroundings and the bottom.

The calculated correlations of averaged within the zones Ellenberg's indicators are presented in Table 3. At the bottom of the niche, the light indicator L is strongly correlated with the moisture indicator F (0.607). On the slope, the moisture indicator $\mathrm{F}$ is correlated with temperature $\mathrm{T}(0.551)$ and reaction $\mathrm{R}(0.520)$. In the surrounding area, the indicator of moisture $\mathrm{F}$ is correlated with $\mathrm{L}, \mathrm{N}$ and $\mathrm{R}$ (correlation: $0.612,0.627$ and 0.552 , respectively), and the indicator $\mathrm{R}$ is correlated with $\mathrm{L}(0.512)$ and $\mathrm{R}$ with $\mathrm{N}(0.582)$.

\subsection{Comparative analysis of the vegetation cover and habitat types}

Canonical Correspondence Analysis (CCA) performed for vascular species and types of habitats is presented in Figure 6. Species of mostly drier habitats (from the classes Artemisietea vulgaris and Stelarietea mediae), and grassland species (from the class Molinio-Arrhenatheretea, including mostly mesic grasslands from the order Arrhenatheretalia) are correlated with the surroundings of the niche (Fig 6). Species from the classes: Querco-Fagetea and Artemisietea vulgaris and other forest species are correlated with the slope, including mainly: Maianthemum bifolium, Cystopteris fragilis, Campanula persicifolia, Listera ovata, Lathraea squamaria. Species of wet habitats from the class Phragmitetea (Scutellaria galericulata, Epilobium roseum, Carex paniculata, Veronica beccabunga, Scrophullaria umbrosa, Glyceria nemoralis, Galium palustre and Berula erecta), the class Alnetea glutinosae (Alnus glutinosa, Thelypteris palustris, Solanum dulcamar and Ribes nigrum), the class Lemnetea (Lemna minor and L. trisulca), the class Montio-Cardaminetea (Cardamine amara, Carex remota, Chrysosplenium alternifolium) and Scheuchzerio-Caricetea nigrae (Epilobium palustre) are placed on the right side of the diagram. Also species of wet meadows from the class Molinio-Arrhenatheretea, mainly from the order Molinietalia were clustered in this part of the diagram, e.g. Cirsium oleraceum, Scirpus sylvaticus, Myosotis palustris. The slope and the surroundings are the factors accounting for the distribution of species in the ordination space (correlation with the second axis is -0.88 and 0.82 , respectively). Water seepage and water flow have the strongest correlation with the first axis (correlation 0.77 and 0.64 , respectively). The surrounding is also negatively correlated with the first axis (correlation -0.56). The water flow is strongly correlated with the third axis (0.85), and the clusters of trees with the fourth axis (0.9). The ordination of species clearly indicates that the first axis represents the increasing moisture gradient. Factors determining the distribution of species along the second axis are most probably light and temperature (Table 4). The first CCA axes account for $85.1 \%$ of the variance of species-environment relations (Table 5).

The Canonical Correspondence Analysis (CCA) carried out on plant communities and types of habitats (Fig. 7) re- 


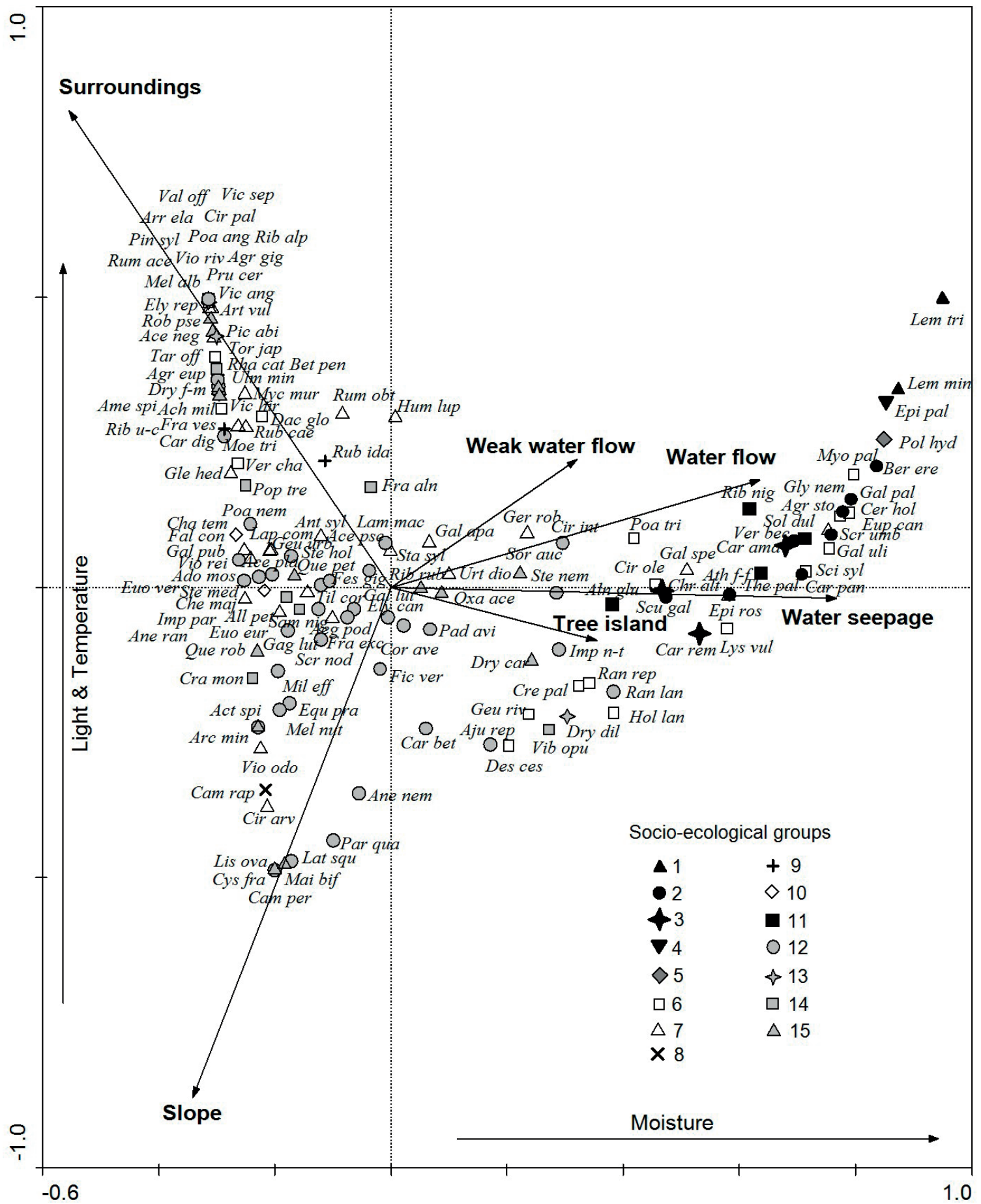

Figure 6. CCA ordination diagram of flora and habitat types; 1 - Lemnetea minoris, 2 - Phragmitetea australis, 3 - Montio-Cardaminetea, 4 - Scheuchzerio-Caricetea nigrae, 5-Bidentetea tripartiti, 6-Molinio-Arrhenetheretea, 7 - Artemisietea vulgaris, 8 - Trifolio-Geranietea sanguinei, 9 - Epilobietea angustilolii, 10 - Stellarietea mediae, 11 - Alnetea glutinosae, 12 - Querco-Fagetea, 13 - Vaccinio-Piceetea, 14 - Rhamno-Prunetea, 15 - other non-forest 
Table 4. Correlation coefficients of share of individual habitat types with CCA axes for vascular plant species

\begin{tabular}{|l|c|c|c|c|}
\hline \multicolumn{1}{|c|}{ Habitat types } & $\begin{array}{c}\text { Envi. } \\
\mathbf{A x 1}\end{array}$ & $\begin{array}{c}\text { Envi. } \\
\mathbf{A x 2}\end{array}$ & $\begin{array}{c}\text { Envi. } \\
\mathbf{A x 3}\end{array}$ & $\begin{array}{c}\text { Envi. } \\
\mathbf{A x 4}\end{array}$ \\
\hline Water flow & 0.6350 & 0.1842 & 0.1772 & -0.0453 \\
\hline $\begin{array}{l}\text { Weak water } \\
\text { flow }\end{array}$ & 0.3202 & 0.2200 & 0.8508 & 0.0887 \\
\hline Water seepage & 0.7667 & -0.0192 & -0.4214 & -0.3466 \\
\hline Tree islands & 0.3544 & -0.0918 & -0.1717 & 0.9040 \\
\hline Slope & -0.3409 & -0.8778 & 0.2708 & -0.1710 \\
\hline Surroundings & -0.5546 & 0.8207 & -0.1307 & 0.0207 \\
\hline
\end{tabular}

Table 5. Cumulative percentage variance of species-environment relations in CCA for vascular plant species

\begin{tabular}{|c|c|c|c|c|}
\hline \multirow{2}{*}{$\begin{array}{c}\text { Cumulative } \\
\text { percentage } \\
\text { variance }\end{array}$} & Axis 1 & Axis 2 & Axis 3 & Axis \\
\hline & 70.7 & 85.1 & 94.6 & 98.2 \\
\hline
\end{tabular}

Table 6. Correlation coefficients of share of individual habitat types with CCA axes for plant communities

\begin{tabular}{|l|c|c|c|c|}
\hline \multicolumn{1}{|c|}{ Habitat types } & $\begin{array}{c}\text { Envi. } \\
\text { Ax1 }\end{array}$ & $\begin{array}{c}\text { Envi. } \\
\text { Ax2 }\end{array}$ & $\begin{array}{c}\text { Envi. } \\
\text { Ax3 }\end{array}$ & $\begin{array}{c}\text { Envi. } \\
\text { Ax4 }\end{array}$ \\
\hline Water flow & 0.5929 & -0.2037 & 0.1286 & -0.5604 \\
\hline Weak water flow & 0.2837 & -0.1518 & 0.8896 & 0.2965 \\
\hline Water seepage & 0.6945 & -0.0908 & -0.4865 & 0.4994 \\
\hline Tree islands & 0.4486 & -0.0989 & 0.0233 & -0.2869 \\
\hline Slope & -0.2485 & 0.9599 & 0.1123 & -0.0365 \\
\hline Surroundings & -0.6978 & -0.7153 & -0.0348 & 0.0012 \\
\hline
\end{tabular}

Table 7. Cumulative percentage variance of species-environment relations in CCA for plant communities

\begin{tabular}{|c|c|c|c|c|}
\hline $\begin{array}{c}\text { Cumulative } \\
\text { percentage } \\
\text { variance }\end{array}$ & Axis 1 & Axis 2 & Axis 3 & Axis 4 \\
\cline { 2 - 5 } & 42.4 & 70.5 & 87.5 & 95.2 \\
\hline
\end{tabular}

vealed three groups of plant communities correlated with a specific type of habitat. Non-forest communities are correlated with habitats characterised by the highest moisture content (water seepage and water flow): Lemnetum trisulcae, Glycerietum plicato-nemoralis, Cardamino-Beruletum erecti and Eupatorietum cannabini as well as forest and thicket communities: developmental stages of Cardamino-Alnetum, the Ribes nigrum community, Fraxino-Alnetum and Carici remotae-Fraxinetum. Tilio-Carpinetum corydaletosum and the Acer platanoides-Tilia cordata community develop on the slope. Tilio-Carpinetum occur around the niche. Factors accounting for the distribution of communities in the diagram are habitat conditions prevailing in the surroundings and on the slope. The correlation of the vector representing the surrounding area with the first axis is -0.69 (Table 6) and the correlation between the vector representing the slope and the second axis is 0.95 . Furthermore, the first axis is correlated with water seepage (correlation 0.69) and the water flow (correlation 0.59). The second axis is correlated with the surrounding area (0.71). The third axis is correlated with reduced water flow (0.86). Like in the case of species, the distribution of plant communities in the ordination space is correlated with the substrate moisture content, which increases from the left to the right side of the diagram, and with the temperature and light, which increase towards the lower part of the diagram In the CCA analysis of plant communities and habitat types, the first axes account for $70,5 \%$ of the variance of species-environment relations (Table 7).

The Monte Carlo permutation test showed that the habitat heterogeneity significantly affects both the distribution of species and the distribution of plant communities in the spring area $(\mathrm{p}<0.05)$.

\section{Discussion}

The diversity and the distribution of species and plant communities within the limits of the spring ecosystem are significantly affected by the erosion processes induced by groundwater seeps, which consequently determines the geomorphology of the area and contributes to the habitat heterogeneity. Some plant communities develop in places of extensive water seepage and accumulation of organic matter, others in places with the reduced water flow and sand-gravel substrate (Osadowski, 2010). Specific habitat conditions develop also on the slope through the erosion processes.

The averaged values of ecological indicators ( $\mathrm{L}, \mathrm{T}, \mathrm{F}$, $\mathrm{R}, \mathrm{N}$ and $\mathrm{K}$ ) obtained for all plots considerably vary and follow a zonal arrangement. The zones distinguished as a result of phytoindication analysis overlap with the outline of the slope edge and the bottom of the niche as obtained by field mapping (Figs 2 and 4). Higher values of the light indicator $\mathrm{L}$ in the plots at the bottom of the niche result 


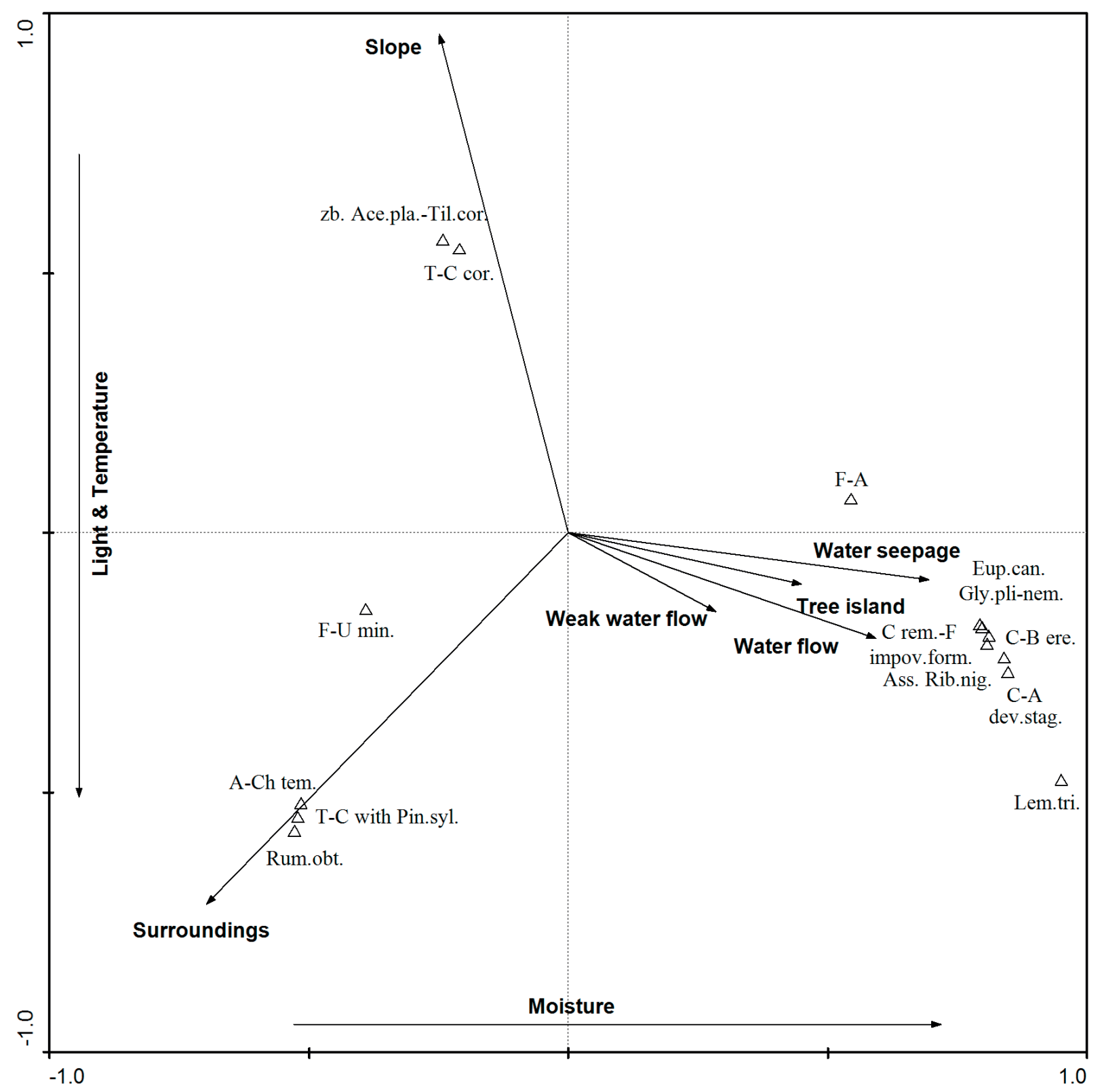

Figure 7. CCA ordination diagram of plant communities and habitat types; Lem.tri. - Lemnetum trisulcae, Gly.pli-nem. - Glycerietum plicato-nemoralis, C-B ere. - Cardamino-Beruletum erecti, Eup.can. - Eupatorietum cannabini, A-Ch tem. Alliario-Chaerophylletum temuli, Rum.obt. - Rumicetum obtusifolii, C-A dev.stag. - Cardamino-Alnetum developmental stages, Ass.Rib.nig. - Ribes nigrum community, F-A - Fraxino-Alnetum, C rem.-F. impov.form. - Carici remotae-Fraxinetum impoverished form, F-U min. - Ficario-Ulmetum minoris, T-C typ. with Pin.syl. - Tilio-Carpinetum typicum form with Pinus sylvestris, T-C cor. - Tilio-Carpinetum corydaletosum, Ass. Ace.pla.-Til.cor. - Acer platanoides-Tilia cordata community

from the increased amount of sunlight reaching the bottom. This is connected with the structure of the tree layer and the undergrowth, which is determined by the existing places of water seepage and water flow. The layer of trees is built of single alder trees forming islands. The shrub layer is characterised by small density. High heterogeneity of habitats associated with the presence of water seepage is reflected in a wide range of moisture indicator $F$ values at the bottom of the niche (from 3.29 to 9.08). Higher values of this indicator were recorded at the plots dominated by seeps and streams. Single plots with lower values of the indicators $\mathrm{L}$ and $\mathrm{F}$ overlap with the islands of trees. Those 
are places where authogenic soil develops; they are more shaded by deciduous species and provide habitat for terrestrial taxa. Non-forest communities develop at the bottom of the niche at exposed sites. The temperature indicator $\mathrm{T}$ had higher values at plots situated on the slope, which facilitates the encroachment of heliophilous and thermophilous species. This is reflected in high values of the standard deviation obtained for ecological indicators at the study plots located at the bottom, which results from highly mosaic habitats and the occurrence of species with different preferences. The slope has the smallest standard deviation range due to homogeneous habitat conditions.

A total of 143 vascular species were identified in the study area. Floristic richness of this area results mostly from habitat heterogeneity. The soil moisture content is the main factor accounting for the distribution of species. The highest species richness was observed in the study plots located on the slope (median - 15 species), the lowest at the bottom of the niche (median - 13 species). Heliophilous species and species preferring fertile and moderately wet habitats occur on the slope. This is confirmed by the research on species richness and species composition along the moisture gradient (Hettenbergerová et al. 2013) which shows that the highest species richness occurs on habitats with average soil moisture content (37-60\%). Similarly as in the spring areas in the Czech Republic, Crepis paludosa, Scirpus sylvaticus and Eupatorium cannabinum occur in places with the highest moisture content, whereas e.g. Arrhenatherum elatius, Glechoma hederacea and Veronica chamaedrys occur at the surrounding sites with much lower moisture content (Hettenbergerová et al., 2013).

Characteristic species of the class Montio-Cardaminetea occur at the bottom of the niche. Carex remota and Chrysosplenium alternifolium are associated with places of water seepage, whereas Cardamine amara shows affinity with both the seeps and the streams. It follows also from the study by Osadowski (2010) that the Carex remota and Chrysosplenium alternifolium occur with higher constancy in communities developing on boggy ground, and Cardamine amara in communities growing on hard substrate and in outflows from spring areas.

When comparing the number of species, a total of 447 species of vascular plants were identified in 50 spring areas of northern Poland (Osadowski, 2008). The occurrence of 177 species of vascular plants was determined in the Swiss Alps at 27 study plots of $16 \mathrm{~m}^{2}, 163$ species in the Carpathians (31 plots), 137 taxa in Bulgaria (20 plots) (Sekulová et al., 2012). One of the aspects in the exploration of mountain spring ecosystems is their species richness in relation to chemical properties of water and soil. Hájkova and Hájek (2003) analysed species richness in the Western Carpathians on the plots of varying size ranging from $0.00196 \mathrm{~m}^{2}$ to $16 \mathrm{~m}^{2}$. The results of these studies indicate an increase in the number of species with an increase in the size of plots, and a high correlation of species richness with an increase in $\mathrm{pH}$, conductivity, concentration of calcium and magnesium in spring waters. A similar relationship between species richness and mineral resources was evidenced by Sekulová et al. (2011).

As many as 14 vegetation units were identified in the study area of ca. 0.4 ha. Ten plant communities from five phytosociological classes were identified only within the range of the bottom and the slope.

The distribution of phytocoenoses within the limits of the study area shows a nearly concentric pattern, which is related to geomorphology of the spring niche. On the slopes mostly develops the Acer platanoides-Tilia cordata community, while the bottom is covered with riparian forest vegetation. Places with a mosaic of streams, seeps with accumulated organic matter and clumps of trees are occupied by Carici remotae-Fraxinetum. Fraxino-Alnetum grows in wet, sometimes boggy places in the vicinity of streams. Whereas Cardamino-Alnetum covers habitats with the accumulated organic matter, often in uplifted places (Herbich, 1994; Wołejko et al., 1994; Wołejko, 2000; Gawenda-Kempczyńska, 2008).

The comparison of the distribution of temperature indicator values with the map of actual vegetation shows that the Acer platanoides-Tilia cordata community develops in the north-western part of the slope with high $\mathrm{T}$ values. This is connected with the south-eastern slope exposure and is reflected in the presence of thermophilic species. Associations Ficario-Ulmetum minoris and Tilio-Carpinetum corydaletosum occur at the study plots with the nutrient availability indicator $\mathrm{N}$ above 5 . Carici remotae-Fraxinetum occurs in the mosaic with clumps of trees and streams, and thus at places with high values of light $\mathrm{L}$ and moisture F indicators. According to the study by Douda (2008) on the classification of forest vegetation from moist habitats in the Czech Republic, there is a correlation between riparian forests Ficario-Ulmetum campestris and e.g. the indicators of nutrient availability $\mathrm{N}$, temperature $\mathrm{T}$ and reaction $\mathrm{R}$. Whereas the occurrence of the Carici remotae-Fraxinetum association in spring ecosystems is correlated with the light $\mathrm{L}$ and moisture $\mathrm{F}$ indicators.

Plant communities from the class Montio-Cardaminetea were not found in the study area. This is due to the fact that only vascular plants were included in the analysis, while bryophytes, although being a significant component of the associations from this class, were excluded. Furthermore, the literature on the vegetation of lowland spring ecosystems provides evidence that northern Poland is located outside the range of typical spring habitat vegetation (Wołejko, 2000; Osadowski, 2010), described from mountain regions (Kornaś \& Medwecka-Kornaś, 1967; Hájek et al., 2005; Kliment et al., 2008; Sekulová et al., 2011; Chytrý, 2012). Non-forest phytocoenoses, characteristic of spring ecosystems develop at the bottom of the niche, 
e.g. Glycerietum plicato-nemoralis, Cardamino-Beruletum erecti and Lemnetum trisulcae. The first one develops in marshy places with extensive water seepage, the second one - in streams (Osadowski, 2010).

In the lowland part of Poland, the association Carici remotae-Fraxinetum is associated with spring ecosystems (Herbich, 1994; Cyzman, 1995; Kępczyński \& Cyzman, 1995; Jutrzenka-Trzebiatowski \& Dziedzic, 1994; Kucharski \& Filipiak, 1999). In the study area, the association occurs in the lowland form, which differs from the typical form in a smaller contribution of montane species. No characteristic species, such as Equisetum telmateia and Rumex sanguineus were found in the study area, while Circaea intermedia occurs with small abundance (Matuszkiewicz, 2001).

High richness of plant communities over a relatively small area has been also reported by other authors. The presence of 29 syntaxa from 6 vegetation classes was confirmed in two spring areas in western Poland (the drainage basin of the Parsęta River) (Osadowski et al., 2009). In the report on 122 spring areas in north-western Poland, Osadowski (2010) describes 13 plant communities from 3 vegetation classes found only in places with groundwater outflow and seepage. Wołejko (2000) identified 85 syntaxonomic units from 7 classes in 25 lowland spring ecosystems.

The great importance of natural spring ecosystems is evidenced by the presence of plant communities recognized as Natura 2000 sites, e.g. Carici remotae-Fraxinetum, Ficario-Ulmetum and Tilio-Carpinetum in the study area (Herbich, 2004; Gawenda-Kempczyńska, 2008; Obwieszczenie Ministra Środowiska, 2014).

The existing literature compares the sites supplied by groundwater but does not explain the ecological conditions affecting the distribution of plant communities and plant species within a spring niche (Beierkuhnlein \& Gräsle, 1998; Wheeler \& Proctor, 2000; Hájek et al., 2002; Hájková et al., 2004; Audorf et al., 2009; Strohbach et al., 2009; Audorf et al., 2011). The research on the impact of hydrochemical factors on the vegetation cover of spring areas in Central Europe revealed that the plant species composition and the plant species diversity are determined in these ecosystems, besides a moisture, by $\mathrm{pH}$ of water (seasonally stable), which consequently affects the availability of nutrients (Hájek \& Hekera, 2004). The research of Osadowski (2010) on the lowland spring areas confirms that apart from hydrochemical parameters of the water (the content of bicarbonates and calcium), also geological structure, hydrological conditions and land relief affect the heterogeneity of the vegetation. In addition to $\mathrm{pH}$, also light is indicated in the available literature as a factor affecting the species composition of plant communities in spring areas. The light is of particular importance in areas located in forests (Hinterlang, 1992; Beierkuhnlein \& Gräsle, 1998; Peintinger \& Beierkuhnlein, 1999).

The results presented in this paper indicate that spring areas are characterised by relatively high heterogeneity of the habitat, which primarily results from the presence of groundwater outflows. The seeping water induces erosion processes and contributes to habitat heterogeneity (e.g. the slope of the niche, islands of trees, streams). Through their impact on the moisture, light and temperature, the hydrological and geomorphological conditions affect the specific flora and vegetation of spring ecosystems.

\section{References}

Alfaro C. \& Wallace M., 1994, Origin and classification of springs and historical review with current applications, Environ. Geol. 24: 112-124.

Audorf V., Kapfer J. \& Beierkuhnlein C., 2009, Inter-annual vegetation dynamics in forest springs, [in:] V. Audorff (ed.), Vegetation ecology of springs: ecological, spatial and temporal patterns, Bayreuth: BayCEER-online 5: 91-106.

Audorf V., Kapfer J. \& Beierkuhnlein C., 2011, The role of hydrological and spatial factors for the vegetation of Central European springs, J. Limnol. 70 (Suppl. 1): 9-22.

Beierkuhnlein C., 1999a, Quellflurgesellschaften an helokrenen Waldquellen der silikatischen Mittelgebirge, Bay. For. Ökol. 71: 143-153.

Beierkuhnlein C., 1999b, Vegetation der Waldquellfluren im Frankenwald, Bay. For. Ökol. 71: 155-172.

Beierkuhnlein C. \& Gräsle W., 1998, The influence of light regime and water chemistry on the structure of forest spring vegetation, [in:] L. Botosaneanu (ed.), Studies in crenobiology: the biology of springs and springbrooks, Backhuys Publishers, Leiden.

Beierkuhnlein C. \& Schmidt J., 1999, Vegetation der Waldquellfluren im Thüringer Schiefergebirge, Bay. For. Ökol. 71: 173-183.

Bohn U., 1996, Vegetationskarte der Bundesrepublik Deutschland Potentielle natürliche Vegetation Blatt CC 5518 Fulda 1:200 000, Schr. Reihe Vegetationskunde 15: $1-364$.

Brzeg A. \& Wojterska M., 2001, Zespoły roślinne Wielkopolski, ich stan poznania i zagrożenie [Plant associations in the region of Wielkopolska, the state of their recognition and threats], [in:] M. Wojterska (ed.), Szata roślinna Wielkopolski i Pojezierza Południowopomorskiego. Przewodnik sesji terenowych 52 Zjazdu PTB, 24-28 września 2001 [Vegetation cover of the Wielkopolska Region and the South Pomeranian Lake District, Guidebook to field sessions of the 52nd Pol- 
ish Botanical Society Convention, 24-28 September, 2001], Bogucki Wyd. Nauk., Poznań: 39-110.

Chytrý M., 2012, Vegetation of the Czech Republic: diversity, ecology, history and dynamics, Preslia 84: 427-504.

Diekmann M., 2003, Species indicator values as an important tool in appliedplant ecology - a review, Basic Appl. Ecol. 4: 493-506.

Douda J., 2008, Formalized classification of the vegetation of alder carr and floodplain forests in the Czech Republic, Preslia 80: 199-224.

Ellenberg H., Weber H.E., Düll R., Wirth V. \& Werner W., 2001, Zeigerwerte von Pflanzen in Mitteleuropa, Scr. Geobot. 18: 1-262.

Faliński J.B., 2002, 15. Vegetation dynamics in spring cirque, [in:] J.B. Faliński (ed.), Long-term studies. Bibliography. Data basis on the vegetation and environment 1952-2002, Białowieża Geobotanical Station of Warsaw University, Phytocoenosis 14(N.S.), Suppl. Bibl. Geobot. 5: 125-128.

Gawenda-Kempczyńska D., 2005, Valuable features of springs in the Górzno-Lidzbark Landscape Park and their conservation, Ecological Questions 6: 39-51.

Gawenda-Kempczyńska D., 2008, Leśne siedliska przyrodnicze w ekosystemach źródliskowych Górznieńsko-Lidzbarskiego Parku Krajobrazowego [Forest habitats in the spring ecosystems of the Górzno-Lidzbark Landscape Park], Przegląd Przyrodniczy 19(1-2): 23-41.

Grootjans A., Alserda A., Bekker R., Janáková M., Kemmers R. \& Madaras M., 2005, Calcareous spring mires in Slovakia; Jewels in the Crown of the Mire Kingdom, Stapfia 85: 97-115.

Grootjans A., Swinkels J., Groeneweg M., Wołejko L. \& Aggenbach C., 1999, Hydro-Ecological aspects of a Polish spring mire complex (Diabli Skok), Crunoecia 6: 73-82.

Hájek M. \& Hekera P., 2004, Can seasonal variation in fen water chemistry influence the reliability of vegetation-environment analyses? Preslia 76: 1-14.

Hájek M., Hekera P. \& Hájková P., 2002, Spring fen vegetation and water chemistry in the Western Carpathian flysch zone, Folia Geobot. 37: 205-224.

Hájek M., Tzonev R., Hájková P., Ganeva A. \& Apostolova I., 2005, Plant communities of the subalpine mires and springs in the Vitosha Mt., Phytol. Balcan. 11(2): 193-205.

Hájková P. \& Hájek M., 2003, Species richness and aboveground biomass of poor and calcareous spring fens in the flysch West Carpathians and their relationships to water and soil chemistry, Preslia 75: 271-287.

Hájková P., Wolf P. \& Hájek M., 2004, Environmental factors and Carpathian spring fen vegetation: the importance of scale and temporal variation, Ann. Bot. Fennici 41: 249-262.
Herbich J., (ed.), 2004, Lasy i Bory. Poradniki ochrony siedlisk i gatunków Natura 2000 - podręcznik metodyczny, T. 5. Warszawa: Ministerstwo Środowiska [Natura 2000 habitat and species protection guides - methodological handbook, Vol. 5. Ministry of the Environment, Warsaw].

Herbich J., 1994, Przestrzenno-dynamiczne zróżnicowanie roślinności dolin w krajobrazie młodoglacjalnym na przykładzie Pojezierza Kaszubskiego [Spatial and dynamical diversity of the vegetation in valleys in a young- glacial landscape exemplified by the Kashubian lakeland (Northern Poland)], Monogr. Bot. 76: $1-175$.

Hettenbergerová E., Hájek M., Zelený D., Jiroušková J. \& Mikulášková E., 2013, Changes in species richness and species composition of vascular plants and bryophytes along a moisture gradient, Preslia 85: 369-388.

Hinterlang D., 1992, Vegetationsökologie der Weichwasserquellgesellschaften zentraleuropäischer Mittelgebirge, Crunoecia 1: 5-117.

Jongman R.H.G., ter Braak C.J.F. \& van Tongeren O.F.R., 1995, Data analysis in community and landscape ecology, UK, Cambridge Univ. Press, Cambridge.

Jutrzenka-Trzebiatowski A., 1995, Zboczowe lasy klonowo-lipowe Aceri-Tilietum Faber 1936 w Polsce Północno-Wschodniej [Slope maple - lime forests Aceri-Tilietum Faber 1936 in north-eastern Poland], Monogr. Bot. 78: 1-78.

Jutrzenka-Trzebiatowski A. \& Dziedzic J., 1994, Charakterystyka przyrodnicza rezerwatu Jar Brynicy [Natural characteristics of the Jar Brynicy nature reserve], Ochrona Przyrody 51: 107-136.

Kapfer J., Audorff V., Beierkuhnlein C. \& Hertel E., 2012, Do bryophytes show a stronger response than vascular plants to interannual changes in spring water quality? Freshw. Sci. 31(2): 625-635.

Kępczyński K. \& Cyzman W., 1995, Szata roślinna projektowanego rezerwatu „Stary Zagaj” koło Skępego [Planzenwelt des projektierten Reservats "Stary Zagaj" in der nähe ortschaft Skępe], Acta Univ. Nic. Copern., Biologia 48(93): 93-136.

Kliment J., Kochjarová J., Hrivnák R. \& Šoltés R., 2008, Spring communities of the Vel'ká Fatra Mts (Western Carpathians) and their relationship to Central European spring vegetation, Polish Bot. J. 53(1): 29-55.

Kløve B., Ala-aho P., Bertrand G., Boukalova Z., Ertürk A., Goldscheider N., Ilmonen J., Karakaya N., Kupfersberger H., Kvœrner J., Lundberg A., Mileusnić M., Moszczynska A., Muotka T., Preda E., Rossi P., Siergieiev D., Šimek J., Wachniew P., Angheluta V. \& Widerlund A., 2011, Groundwater dependent ecosystems. Part I: Hydroecological status and trends, Environmental Science \& Policy 14: 770-781. 
Kornaś J. \& Medwecka-Kornaś A., 1967, Zespoły roślinne Gorców. I. Naturalne i na wpół naturalne zespoły nieleśne [Plant communities of the Gorce Mts. (Polish Western Carpatians). I. Natural and seminatural non-forest communities], Fragm. Florist. Geobot. 13(2): 167-316.

Kucharski L. \& Filipiak E., 1999, Szata roślinna obszarów źródliskowych środkowej Polski i jej ochrona [Plant cover of spring areas of central Poland and its conservation] [in:] E. Biesiadko, S. Czachorowski (eds), Źródła Polski. Stań badań, monitoring i ochrona [Polish springs. Research advances, monitoring and protection], Studia i Materiały WSP w Olsztynie 145: 87-94.

Łachacz A., 1999, Torfowiska źródliskowe Polski północno-wschodniej [Spring-water bogs in north-eastern Poland], [in:] E. Biesiadko, S. Czachorowski S. (eds), Źródła Polski. Stan badań, monitoring i ochrona [Polish springs. Research advances, monitoring and protection], Studia i Materiały WSP w Olsztynie 145: 111121.

Mass F.M., 1959, Bronnen, bronbeken en bronbossen van nederland, in het bijzonder die van de veluwezoom. Een plantensociologische en oecologische studie [Springs, springbrooks and springwoods of the Netherlands, especially those of the "veluwezoom". A phytosociological and ecological study], Meded. Land. Wag., Nederland 59 (12): 1-166.

Matuszkiewicz W., 2001, Przewodnik do oznaczania zbiorowisk roślinnych Polski [Guide for the determination of Polish plant communities], Wydawnictwo Naukowe PWN, Warszawa.

Mirek Z., Piękoś-Mirkowa H., Zając A. \& Zając M., 2002, Flowering plants and Pteridophytes of Poland. A checklist, W. Szafer Institute of Botany, Polish Academy of Science, Kraków.

Obwieszczenie M.Ś. z dn. 30 października 2014, Poz. 1713, w sprawie ogłoszenia jednolitego tekstu rozporządzenia Ministra Środowiska w sprawie siedlisk przyrodniczych oraz gatunków będących przedmiotem zainteresowania Wspólnoty, a także kryteriów wyboru obszarów kwalifikujących się do uznania lub wyznaczenia jako obszary Natura 2000 [Notice of the Minister of the Environment dated 30 October 2014, Item 1713 , on the publication of the consolidated text of the Regulation of the Minister of the Environment on natural habitats and species of the Community interest, and criteria for selection of areas eligible for recognition or designation as Natura 2000 sites].

Osadowski Z. \& Żukowska A., 2009, Rare and endangered species in spring complexes of the Skotawa river valley (Central Pomerania, in Poland), [in:] Z. Mirek, A. Nikiel (eds), Rare, relict and endangered plants and fungi in Poland, W. Szafer Institute of Botany, Polish Academy of Sciences, Kraków: 389-397.
Osadowski Z., 2000, Transformations of the Spring-complexes' Vegetation on the Area of the Upper Parsęta Catchment, [in:] B. Jackowiak, W. Żukowski (eds), Mechanisms of anthropogenic changes of the plant cover, Publications of the Department of Plant Taxonomy of the Adam Mickiewicz University, Poznań, 10: 249-257.

Osadowski Z., 2008, The state of preservation and the protection needs of spring vegetation in central Pomerania, Oceanol. Hydrobiol. St. 37(1): 81-90.

Osadowski Z., 2010, Wpływ uwarunkowań hydrologicznych i hydrochemicznych na zróżnicowanie szaty roślinnej źródlisk w krajobrazie młodoglacjalnym Pomorza [The infuence of hydrological and hydrochemical conditions on vegetation cover diversity in spring areas of the postglacial landscape in the Pomeranian region], Bogucki Wydawnictwo Naukowe, Poznań-Słupsk.

Osadowski Z., Mazurek M. \& Dobrowolski R., 2009, Structure and development conditions of spring mires in the Parsęta basin (Western Pomerania), [in:] A. Łachacz (ed.), Wetlands - their functions and protection. Department of Land Reclamation and Environmental Management, , University of Warmia and Mazury in Olsztyn 2: 107-124.

Peintinger P. \& Beierkuhnlein C., 1999, Vegetation der Waldquellfluren im Thüringer Wald, Bay. For. Ökol. 71: 185-196.

Sekulová L., Hájek M., Hájková P., Mikulášková E., Buttler A. \& Syrovátka V., 2012, Patterns of bryophyte and vascular plant richness in European subalpine springs, Plant Ecol. 213: 237-249.

Sekulová L., Hajek M., Hajkova P., Mikulaškova E. \& Rozbrojova Z., 2011, Alpine wetlands in the West Carpathians: vegetation survey and vegetation-environment relationships, Preslia. 83: 1-24.

Springer A.E. \& Stevens L.E., 2009, Spheres of discharge of springs, Hydrogeol. J. 17(1): 83-93.

Strohbach M., Audorff V. \& Beierkuhnlein C., 2009, Drivers of species composition in siliceous spring ecosystems: groundwater hydrochemistry, catchment traits or spatial factors? J. Limnol. 68: 375-384.

ter Braak C.J.F., 1986, Canonical correspondence analysis: a new eigenvector technique for multivariate direct gradient analysis, Ecology 67: 1167-1179.

ter Braak C.J.F. \& Šmilauer P., 2002, CANOCO reference manual and CanoDraw for Windows user's guide: software for canonical community ordination (version 4.5). Microcomputer Power, Ithaca, NY, USA.

Wheeler B.D. \& Proctor M.C.F., 2000, Ecological gradients, subdivisions and terminology of north-west European mires, J. Ecol. 88: 187-203.

Wołejko L., 1991, Porównanie kompleksów źródliskowych rozwijających się w warunkach naturalnych i zmienionych w wyniku antropopresji. I. Ekologiczne zróżni- 
cowanie biotopów [The development of spring ecosystems in natural conditions and under human impact. I. Environmental conditions], Fol. Univ. Agric. Stetin. 149, Agricultura 51: 53-67.

Wołejko L., 2000, Dynamika fitosocjologiczno-ekologiczna ekosystemów źródliskowych Polski północno-zachodniej w warunkach ekstensyfikacji rolnictwa [Plant-sociological and ecological dynamics of spring ecosystems in NW Poland under conditions of decreasing intensity of agriculture], Wyd. Akademii Rolniczej, Rozprawy, 195, Szczecin.

Wołejko L., 2002, Soligenous wetlands of north-western Poland as an environment for endangered mire species, Acta Soc. Bot. Pol. 71(1): 49-61.

Wołejko L., Aggenbach C., van Diggelen R. \& Grootjans A.P., 1994, Vegetation and hydrology in a spring mire complex in Westen Pomerania, Poland. Proc. Kon. Ned. Akad. Wetensch. 97(2): 219-245.

Załuski T. \& Gawenda D., 1999, Różnorodność szaty roślinnej młak źródliskowych w okolicach Górzna [Diversity of plant cover of spring mires in the vicinity of Górzno], Fol. Univ. Agric. Stetin. 197, Agricultura 75: 367-371.

Załuski T., Paszek I., Gawenda-Kempczyńska D., Iglińska A. M. \& Szczepański M., 2004, Ostoje cennej szaty roślinnej na Pojezierzu Dobrzyńskim i Równinie Urszulewskiej [Refuges of valuable flora and vegetation in Dobrzyń Lakeland and Urszulewo Plain], [in:] E. Krasicka-Korczyńska, M. Korczyński (eds), Wycieczki geobotaniczne. Region kujawsko-pomorski [Geobotanical excursions. Kujawy-Pomerania Region], Wyd. Oddział PTB w Bydgoszczy, Oddział PTB w Toruniu, Toruń-Bydgoszcz: 87-99.

Zang C., Audorf V. \& Beierkuhnlein C., 2009, Is the delineation of niche attributes a matter of spatial scale?, [in:] V. Audorff (ed.), Vegetation ecology of springs: ecological, spatial and temporal patterns, Bayreuth: BayCEER-online 5: 69-90.

Zechmaister H. \& Mucina L., 1994, Vegetation of European springs: High-rank syntaxa of the Montio-Cardaminetea, J. Veg. Sci. 5: 385-402. 